\title{
Front Matter: Volume 9059
}

, "Front Matter: Volume 9059," Proc. SPIE 9059, Industrial and Commercial Applications of Smart Structures Technologies 2014, 90591B (5 May 2014); doi: $10.1117 / 12.2064702$

Event: SPIE Smart Structures and Materials + Nondestructive Evaluation and Health Monitoring, 2014, San Diego, California, United States 


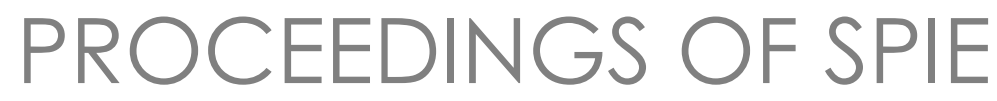

\section{Industrial and Commercial Applications of Smart Structures Technologies 2014}

Kevin M. Farinholt

Steven F. Griffin

Editors

11-12 March 2014

San Diego, California, United States

Sponsored by

SPIE

Cosponsored by

American Society of Mechanical Engineers (United States)

Cooperating Organizations

Intelligent Materials Forum (Japan)

Jet Propulsion Laboratory (United States)

National Science Foundation (United States)

Published by

SPIE 
The papers included in this volume were part of the technical conference cited on the cover and title page. Papers were selected and subject to review by the editors and conference program committee. Some conference presentations may not be available for publication. The papers published in these proceedings reflect the work and thoughts of the authors and are published herein as submitted. The publisher is not responsible for the validity of the information or for any outcomes resulting from reliance thereon.

Please use the following format to cite material from this book:

Author(s), "Title of Paper," in Industrial and Commercial Applications of Smart Structures Technologies 2014, edited by Kevin M. Farinholt, Steven F. Griffin, Proceedings of SPIE Vol. 9059 (SPIE, Bellingham, WA, 2014) Article CID Number.

ISSN: 0277-786X

ISBN: 9780819499851

Published by

SPIE

P.O. Box 10, Bellingham, Washington 98227-0010 USA

Telephone +1 3606763290 (Pacific Time) · Fax +1 3606471445

SPIE.org

Copyright (C) 2014, Society of Photo-Optical Instrumentation Engineers.

Copying of material in this book for internal or personal use, or for the internal or personal use of specific clients, beyond the fair use provisions granted by the U.S. Copyright Law is authorized by SPIE subject to payment of copying fees. The Transactional Reporting Service base fee for this volume is $\$ 18.00$ per article (or portion thereof), which should be paid directly to the Copyright Clearance Center (CCC), 222 Rosewood Drive, Danvers, MA 01923. Payment may also be made electronically through CCC Online at copyright.com. Other copying for republication, resale, advertising or promotion, or any form of systematic or multiple reproduction of any material in this book is prohibited except with permission in writing from the publisher. The CCC fee code is 0277-786X/14/\$18.00.

Printed in the United States of America.

Publication of record for individual papers is online in the SPIE Digital Library.

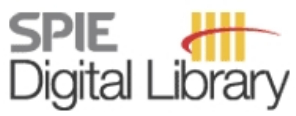

SPIEDigitalLibrary.org

Paper Numbering: Proceedings of SPIE follow an e-First publication model, with papers published first online and then in print and on CD-ROM. Papers are published as they are submitted and meet publication criteria. A unique, consistent, permanent citation identifier (CID) number is assigned to each article at the time of the first publication. Utilization of CIDs allows articles to be fully citable as soon as they are published online, and connects the same identifier to all online, print, and electronic versions of the publication. SPIE uses a six-digit CID article numbering system in which:

- The first four digits correspond to the SPIE volume number.

- The last two digits indicate publication order within the volume using a Base 36 numbering

system employing both numerals and letters. These two-number sets start with 00, 01, 02, 03, 04, $05,06,07,08,09,0 A, 0 B \ldots$. 0Z, followed by 10-1Z, 20-2Z, etc.

The CID Number appears on each page of the manuscript. The complete citation is used on the first page, and an abbreviated version on subsequent pages. Numbers in the index correspond to the last two digits of the six-digit CID Number. 


\section{Contents}

vii Conference Committee

SESSION 1 SYNTHETIC JETS

905902 Development and test of synthetic jet actuators based on dual transducer concept [9059-2]

M. Schueller, P. Wiegel, M. Lipowski, Fraunhofer-Institut für Elektronische Nanosysteme (Germany); R. Schulze, Technische Univ. Chemnitz (Germany); T. Otto, T. Gessner, Fraunhofer-Institut für Elektronische Nanosysteme (Germany) and Technische Univ. Chemnitz (Germany)

905903 Displacement amplified synthetic jets [9059-3]

S. Griffin, S. M. Haar, E. Whalen, The Boeing Co. (United States)

\section{SESSION 2 ULTRASONIC ADDITIVE MANUFACTURING}

905906 Interfacial shear strength estimates of NiTi-Al matrix composites fabricated via ultrasonic additive manufacturing [9059-6]

A. Hehr, J. Pritchard, M. J. Dapino, The Ohio State Univ. (United States)

905907 Stiffness tuning of FeGa structures manufactured by ultrasonic additive manufacturing [9059-7]

J. J. Scheidler, M. J. Dapino, The Ohio State Univ. (United States)

905908 Optimal welding parameters for very high power ultrasonic additive manufacturing of smart structures with aluminum 6061 matrix [9059-8]

P. J. Wolcott, A. Hehr, M. J. Dapino, The Ohio State Univ. (United States)

\section{SESSION 3 SMART SYSTEMS: ENABLING TECHNOLOGIES}

905909 Piezoelectric-based electrical energy harvesting and storage methods and electronics for munitions [9059-9]

J. Rastegar, Omnitek Partners, LLC (United States); C. Pereira, U.S. Army Armament Research, Development and Engineering Ctr. (United States); M. Ervin, U.S. Army Research

Lab. (United States); D. Feng, Omnitek Partners, LLC (United States)

9059 OA Mechanical and dielectric characterization of Lead Zirconate Titanate(PZT)/polyurethane(PU) thin film composite for energy harvesting [9059-10]

S. Aboubakr, Univ. Chouaib Doukkali (Morocco); M. Rguiti, Univ. de Valenciennes et du Hainaut-Cambrésis (France); A. Hajjaji, A. Eddiai, Univ. Chouaib Doukkali (Morocco);

C. Courtois, S. d'Astorg, Univ. de Valenciennes et du Hainaut-Cambrésis (France) 
9059 OC Model for friction and wear reduction through piezoelectrically assisted ultrasonic lubrication [9059-12]

S. Dong, M. J. Dapino, The Ohio State Univ. (United States)

9059 OD Application of the active camber morphing concept based on compliant structures to a regional aircraft [9059-13]

A. De Gaspari, S. Ricci, Politecnico di Milano (Italy)

9059 OF Recovering strain readings from chirping fiber Bragg gratings in composite overwrapped pressure vessels [9059-15]

S. M. Strutner, Univ. of California, Los Angeles (United States); F. Pena, California State Univ., Los Angeles (United States); A. Piazza, A. R. Parker, W. L. Richards, NASA Dryden Flight

Research Ctr. (United States); G. P. Carman, Univ. of California, Los Angeles (United States)

9059 OG Evaluation of embedded FBGs in composite overwrapped pressure vessels for strain based structural health monitoring [9059-16]

F. Pena, California State Univ., Los Angeles (United States); S. M. Strutner, Univ. of California, Los Angeles (United States); W. L. Richards, A. Piazza, A. R. Parker, NASA Dryden Flight Research Ctr. (United States)

$9059 \mathrm{OH} \quad$ Damper-controlled switch for SMA motion smoothing [9059-22]

C. Aguayo, B. Utter, J. Luntz, R. Gonzalez, D. Brei, Univ. of Michigan (United States);

N. L. Johnson, P. W. Alexander, General Motors Corp. (United States)

POSTER SESSION

9059 Ol Optimal design of a novel configuration of MR brake with coils placed on the side housings [9059-18]

Q. H. Nguyen, N. D. Nguyen, Industrial Univ. of Hochiminh City (Viet Nam); S.-B. Choi, Inha Univ. (Korea, Republic of)

9059 0J Multilevel optimization for the placement of piezo-actuators on plate structures for active vibration control using modified heuristic genetic algorithm [9059-20]

D. Chhabra, Maharshi Dayanand Univ., Rohtak (India); G. Bhushan, P. Chandna, National Institute of Technology, Kurukshetra (India)

$9059 \mathrm{OL}$ Special optical fiber design to reduce reflection peak distortion of a FBG embedded in inhomogeneous material [9059-23]

L.-K. Cheng, P. Toet, J. de Vreugd, R. Nieuwland, TNO (Netherlands); M.-L. V. Tse, H. Tam, The Hong Kong Polytechnic Univ. (Hong Kong, China)

9059 OM A progression of damage repair capability in self-repairing composites [9059-24]

C. Dry, Natural Process Design, Inc. (United States)

9059 ON Comparison of self repair in various composite matrix materials [9059-25]

C. Dry, Natural Process Design, Inc. (United States) 
905900 Sensing of repair in chemically self-repairing composites [9059-26]

C. Dry, Natural Process Design, Inc. (United States)

9059 OP Thixotropic action of self-repairing chemicals to increase strength at first impact [9059-27]

C. Dry, Natural Process Design, Inc. (United States)

Author Index 
Proc. of SPIE Vol. 9059 90591B-6 Downloaded From: https://www.spiedigitallibrary.org/conference-proceedings-of-spie on 25 Apr 2023
Terms of Use: https://www.spiedigitallibrary.org/terms-of-use 


\section{Conference Committee}

Symposium Chairs

Victor Giurgiutiu, University of South Carolina (United States)

Christopher S. Lynch, University of California, Los Angeles

(United States)

\section{Symposium Co-chairs}

Jayanth N. Kudva, NextGen Aeronautics, Inc. (United States)

Theodoros E. Matikas, University of loannina (Greece)

Conference Chair

Kevin M. Farinholt, Luna Innovations Inc. (United States)

Conference Co-chair

Steven F. Griffin, Boeing LTS Inc. (United States)

Conference Program Committee

Eric H. Anderson, CSA Engineering, Inc. (United States)

Steven R. Anton, Los Alamos National Laboratory (United States)

Emil V. Ardelean, Schafer Corporation (United States)

Brandon J. Arritt, Air Force Research Laboratory (United States)

Christian Boller, Fraunhofer-Institut für Zerstörungsfreie Prüfverfahren

(Germany)

Diann E. Brei, University of Michigan (United States)

Alan L. Browne, General Motors Corporation (United States)

Peter C. Chen, NASA Goddard Space Flight Center (United States)

Marcelo J. Dapino, The Ohio State University (United States)

L. Porter Davis, Honeywell Defense and Space Electronic Systems (United States)

Xiao-Yan Gong, Medical Implant Mechanics LLC (United States)

Holger Hanselka, Fraunhofer-Institut für Betriebsfestigkeit und Systemzuverlässigkeit (Germany)

Ernie Havens, Cornerstone Research Group, Inc. (United States)

Nancy L. Johnson, General Motors Corporation (United States)

Chad H. Joshi, Energen, Inc. (United States)

Jayanth N. Kudva, NextGen Aeronautics, Inc. (United States)

Amrita Kumar, Acellent Technologies, Inc. (United States)

Ou Ma, New Mexico State University (United States)

Geoffrey P. McKnight, HRL Laboratories, LLC (United States) 
Christopher Niezrecki, University of Massachusetts Lowell (United States)

Wieslaw M. Ostachowicz, The Szewalski Institute of Fluid-Flow Machinery (Poland)

Gyuhae Park, Chonnam National University (Korea, Republic of)

Marc E. Regelbrugge, Rhombus Consultants Group (United States)

W. Lance Richards, NASA Dryden Flight Research Center (United States)

Janet M. Sater, Institute for Defense Analyses (United States)

Henry A. Sodano, University of Florida (United States)

Wieslaw Jerzy Staszewski, AGH University of Science and Technology (Poland)

Edward V. White, The Boeing Company (United States)

\section{Session Chairs}

1 Synthetic Jets

Kevin M. Farinholt, Luna Innovations Inc. (United States)

2 Ultrasonic Additive Manufacturing

Steven F. Griffin, Boeing LTS Inc. (United States)

3 Smart Systems: Enabling Technologies

Gyuhae Park, Chonnam National University (Korea, Republic of)

Alan L. Browne, General Motors Corporation (United States)

4 Smart Systems: Examples

Kevin M. Farinholt, Luna Innovations Inc. (United States) 